\title{
Empowerment and Collaborative Agency in Roll of Thunder, Hear my Cry
}

\author{
Maher Ben Moussa* \\ Maher Ben Moussa, Arab Open University, Kuwait \\ Corresponding Author: Maher Ben Moussa, E-mail: N.Komesh@yahoo.com
}

\section{ARTICLE INFO}

\section{Article history}

Received: November 06, 2017

Accepted: January 15, 2018

Published: March 01, 2018

Volume: 7 Issue: 2

Advance access: February 2018

Conflicts of interest: None

Funding: None

\begin{abstract}
This article examines the issue of child agency and empowerment in Mildred's D. Taylor's novel Roll of Thunder, Hear my Cry. This theme is addressed by some critics who come to the conclusion that Taylor's protagonist, the young girl Cassie Logan, develops agency and subversive subjectivity in the course of the novel. This study challenges such readings to argue that the ending of Taylor's novel does not reflect empowerment; and consequently does not support such conclusions. Through expanding self-in-relation theory to feminism as an interpretive tool, this paper suggests tha t Cassie Logan's subversive agency remains partial and incomplete because she fails to engage in an inter-connected and constructive relationship with the 'other'. Cassie's empowerment is partial because she fails to exert it in the larger community of African Americans and whites, that otherwise could have stimulated a greater impetus for activism. This study concludes that agency and subjectivity are constructed and empowered within the community which is larger than the self and the family.
\end{abstract}

Key words: Race Relations, Identity, Self in Relation Theory, Collaborative Agency, Child Empowerment
Mildred Taylor's novel Roll of Thunder, Hear My Cry has been critically praised since its publication in 1976. Most critics read it as an example of the Logan family's resistance to racism and racial prejudice prevailing in America in the early $20^{\text {th }}$ Century. The theme of agency and child empowerment is the focus of the critics. Sarah Hardstaff (2015) summarizes the critical reception of the novel by saying, "The novel has also been cited as a powerful exploration of child agency, that is to say, of the capacity of children to change the world around them and challenge injustices" (p. 227). Many see the young African American protagonist Cassie Logan as the focalizer of the novel, who is retrospectively narrating her story of growth and empowerment. The critics argue that Cassie grows through a journey of maturation gaining power and awareness in the course of the novel. Such claims are grounded only partially in some incidents of the novel for these critics do not take into consideration either the ending of the novel or the revengeful nature of Cassie's acts. Looking at the events of the novel through the perspective of self-in-relation theory as an interpretive tool, this study reveals that Cassie Logan's empowerment remains partial and incomplete because she fails to engage in an inter-connected and constructive relationship with 'the other'. Unlike what critics claimed about Cassie's agency, a careful reading of Taylor's novel shows that Cassie's agency is far from being subversive. This study aims to demonstrate how Cassie fails to reach out to the other in order to construct a more subversive collaborative agency with those who partake and share with her the same concerns and aspirations. Cassie does not transform her agency into an impetus for activism but rather nurtures it as an impulse for revenge. The study concludes that real subversive agency and the truly independent subject are constructed and empowered within a community-a community larger than the self and the family.

Having the pattern of a traditional bildungsroman protagonist in mind, the critics Joel Taxel (1986), Pat Pinsent (1997), and Wanda Brooks and Gregory Hampton (2005) perceive Cassie as a character developing from a naïve and vulnerable character to one with agency and empowered through experience. Taxel (1986) describes "Cassie's growth from a naïve, vulnerable child... into one who is wise beyond her years and imbued with the self-confidence necessary for the struggles sure to come" (p. 260). Pinsent (1997) adds, "The reader comes to learn of the racial intolerance through the drawing realizations of the narrator, whose strength grows throughout the novel" (p.85). Wanda Brooks and Gregory Hampton (2005) conclude such a critical perception: "Taylor does not depict this family as a people without some degree of agency and resources" (p. 89).

Jani Baker (2010) elaborates further on the theme of agency and explores how Taylor's Roll of Thunder, Hear My Cry, "provides an analytical dissection of racism that lays bare its structure and workings in 1930s Mississippi and advocates strategic resistance for blacks and whites" (p.120). Kelly McDowell (2009) echoes Baker's claim, "by revealing the ways in which power works, [Cassie's mother] shows 
them how agency is possible" (p. 241). Kelly further argues, "The novel depicts the necessity of child agency as a form of resistance for oppressed cultures" (238). She concludes that "rather than blindly accepting the conditions of their racist society, [children] are prompted to oppose the authority that is forced on them and view themselves as powerful agents of change" (p. 246). McDowell (2009) concludes that children are allowed greater opportunity to act with autonomy "because of the necessity of resistance, [they] are given greater autonomy and treated as subjects, regardless of age, and they work as active agents, just as their elders" (p.224). In her article, 'Papa Said That One Day I would Understand": Examining Child Agency and character Development in Roll of Thunder, Hear My Cry Using Critical Corpus Linguistics', Sarah Hardstaff (2015) presents some variations on the same theme. "By charting linguistic features associated with agency," Hardstaff believes "it is possible to examine character development and ideology with the text" (p.226). Hardstaff illustrates that "the novel's grammatical patterning provides a means of discussing the nature of child agency in Roll of Thunder in new and interesting ways..." (p. 227), and concludes, "The novel's transitivity patterns largely support an interpretation of Cassie's development based on the Bildungsroman model, with Cassie's material agency increasing chapter by chapter, and verbal agency becoming more assertive" (p. 234).

These critics agree that Cassie Logan matures and develops a subversive agency in the course of the novel. However, the ending of the novel does not support such rather ambitious claims about the value and importance of Cassie's agency. The novel closes as follows:

I had never liked T.J., but he had always been there, a part of me, a part of my life, just like the mud and the rain, and I had thought that he always would be. Yet the mud and the rain and the dust would all pass. I knew and understood that. What had happened to T.J. in the night I did not understand, but I knew that it would not pass. And I cried for those things which had happened in the night and would not pass.

I cried for T.J. For T.J. and the land. (Roll of Thunder, p. 339)

The Cassie that we encounter at the end of the novel is not an assertive and active "agent of resistance" and change as some critics claim. Cassie here is lonely, defeated and broken. She is confused. What happened to her neighbor, the African American boy T.J. that night goes beyond her capacity to comprehend. She is just as naïve as she was at the beginning of the novel, and obviously she could not foresee what happened to T.J. even though he is close to her and "part of [her] life just like the mud and the rain." Cassie never tries to reach out to T.J., never understood who he was because as she confesses, "I never liked T.J." Cassie in this scene is disconnected from the land and the people around her. T.J., a part of her, is perhaps going to be lynched, and the future of the land where she finds her roots is not clear. Without both T.J. and the land, Cassie has no clear picture of who she is. Being cut off, Cassie cannot "change the world around [her] and challenge injustices" (Hardstaff, 2015, p. 227). Instead
Cassie is just a passive witness to what is going on around her - a witness who is taken aback by where the course of the events took her, and helpless to reverse her fate, and that of T.J. and her family. Hardstaff's (2015) claim, "The reader sees how Cassie is empowered by her victories" (p. 235) is merely a rhetorical exaggeration.

The agency that Cassie tried to construct for herself is non-productive and her victories are merely acts of sheer emotional revenge with temporary satisfaction and momentary fulfillment. Cassie's acts, which have been perceived as acts of empowerment, are just sheer emotional reactions against the daily mistreatments, injustices, and humiliations that she and her family are exposed to. Cassie's revenge brings her only temporary, fleeting and snappy satisfaction that could have caused more serious and disastrous consequences. Cassie's revenge is well orchestrated; she puts a lot of thought and energy into executing her revenge. She pretends to be a friend to Lilian Jean, apologizes to her again for what happened, and plays the role of a slave in order to gain her trust. Cassie's revenge is justified given the humiliation and the injustice that she was exposed to. However, the result of this revenge does not lead to the empowerment of Cassie. Cassie's revenge does not challenge or subvert the very system that has caused her humiliation; it just changes the position that she and Lillian Jean occupy in this power structure. Cassie was the victim and is now the victimizer, just as Lilian Jean was the victimizer and is now the victim. Both are victims and perpetuators of violence in this bloody circle of 'an eye for an eye'. The balance of power tilts in one direction or the other, but the system as a whole goes unquestioned and unchallenged. On the contrary, the circle where injustice begets revenge and vindictiveness remains unbroken and as intact as it ever was. Cassie gains power and control over Lilian Jean but she never gains the power to change or subvert the existing power structure. Cassie gains control over Lilian Jean and gives her a taste of the bitter humiliation that she herself experienced. In return, Lillian Jean might fear Cassie, but not respect her.

Cassie's anger is legitimate, and she does not need to hold it back. As Kaplan (1986) clarifies, "holding back anger is disempowering and leaves one feeling constricted, ineffective, and perhaps wrong for even feeling angry" (p. 238). However, this anger when channeled in such acts of revenge becomes less constructive and even futile. Kaplan further clarifies that anger "directly and validly expressed - can be an affirming and bonding experience between two people if it occurs in a context of mutuality" (p. 238). Obviously, this is not what happened between Cassie Logan and Lillian Jean. All the time and energy spent in a fake and illusive friendship could have been invested to transform this revenge into a more mutual and "affirming" bond between the two, especially after the secrets shared and the trust that had developed between the two young girls. Cassie's revenge does not liberate her of her pain. It rather confines her to the thick walls of another heavy and dangerous secret that she cannot confess to anyone - a secret that would separate her from her siblings, her peers and her family. With this revenge, as at many other times, Cassie fails to maintain growth-enhancing 
relationships to participate in what Judith Jordan (1995) calls "mutually empowering connections" (p. 53) to construct a collaborative agency that might and could have elevated more of the pain that she and her family are experiencing in the everyday injustices.

The model of self-in-relation is illuminating to understand how Cassie is broken and defeated at the end of the novel and how her often-labeled "subversive agency" is not, in fact, that subversive. This model suggests an alternative sort of empowerment-- the power of a collaborative agency. In contrast to the traditional theories of psychological development which view the self "as the basic unit of study and emphasize its independence, security and separation from other selves," Jordan (1995) shows more interest in "individuals in interaction with one another, interest in relatedness per se and relational development" (p. 52). Jean Miller (2008) states that "people develop by interactions with other people. No one develops in isolation" (p. 369). Surrey (1991) argues, "Personal empowerment can be viewed only through the larger lens of power through connection, that is, through the establishment of mutually empathetic and mutually empowering relationships. Thus, personal empowerment and the relational context through which this emerges must always be considered simultaneously" (p. 164). For Surrey, personal growth can only occur in the context of connection and growth with the other. In her article, "A Relational Approach to Psychotherapy," Jordan (1995) further expands this concept of mutuality and interconnectedness of a self growing in connection with the other:

The movement toward the other's differentness is central to the growth in relationships and also can provide a powerful sense of validation for both self and other. Growth occurs because as I stretch to match or understand your experience, something new is acknowledged or grows in me... (p.57)

In this model, the self merges with the other and its growth takes place in a context of mutuality and co-dependency. The values highlighted in this model are the values of mutuality and reciprocal responsiveness. "Conflict and competition are no longer considered to be the basic human relationships; instead they are being replaced by alternative visions of the foundations of human society derived from nurturance, caring attachments, and mutual interestedness" (Friedman, 1989 p. 276). When such comfortable interdependency occurs and mutual growth-producing relationships develop, according to Collins (1993), "this means moving away on both the personal and political level, from systems based on power and violence and toward systems based on mutual empowerment" (p. 474). Alexander Kaplan (1986) succinctly summarizes the crux of the "self-in-relation model":

Thus, relationship is a two-way interaction, at its best a mutual process where in both parties feel enhanced and empowered through their empathetic connection with the other. Connections with the others, then provides a primary context for action and growth, not a detraction from one's self-enhancement, as implied in other theories (p.235).
This relational-cultural model is not a feel good theory about connection and mutuality. It is indeed a subversive "challenge to the dominant paradigms of separation," (Jordan, 2010, p. 210) be they along the class, gender or racial divides. In this model, "validation occurs because both people in a movement of mutual empathy feel their differentness or uniqueness is acknowledged and accepted. This is not simply a static mirroring process but an expansive growth process for both" (Jordan, 1995, p. 57). As Jordan (2010) summarizes, the relational cultural model challenges "the power of binary thinking that objectifies and creates opposition around difference" (p.212). In Patricia Hill Collins' terms (2000), the relational cultural model can contribute in "developing an epistemology of connection versus an epistemology of separation" (p. 71).

Cassie's relationship with Jeremy Simms, the young white boy in the neighborhood, could have achieved such potential for a more subversive collaborative agency. Jeremy Simms is not a secondary character in the novel, and his role is crucial in the development of the theme of agency and the possibility for a potential collaborative agency based on mutuality and responsiveness. Jeremy's actions in the course of the novel do not testify to what some critics would have us believe. Hardstaff (2015) perceived Jeremy as a passive character with no initiatives. She claims that "although Jeremy is to an extent a sympathetic character, he does not share the collective subjectivity and agency of Cassie and her brothers, hence Jeremy can only 'hurry on to catch Stacey' rather than act, think and feel with him" (p. 234-35). Jeremy is neither a 'scapegoat figure' as Bosmajian (2009, p. 235) claims him to be, nor a "Christ-like" figure who is meant "to forever witness, internalize the wrongs committed against blacks and be an outcast among his own people (Smith, 1994, p. 254-260). A close scrutiny of the turn of events in Roll of Thunder, Hear My Cry reveals that Jeremy does not passively witness and internalize, but he acts and reacts against the injustices and the evils imposed by the white people of his own race on the African American Logan family. Very early at the beginning of the novel, Taylor establishes Jeremy as a faithful and empathetic friend to the Logans who is willing to go against the ideology of his community, the practices of his family and the pressure of his peers, to support the Logans. Jeremy dissociates himself from his white peers and absorbs all the pressure of his sister, brothers and classmates and never rides the bus with them "no matter how bad the weather" (p. 58). Cassie informs the readers: "Ever since I had begun school, he had walked with us as far as the crossroads in the morning, and met us there in the afternoon" (p. 14-15). Jeremy is "ridiculed by the other children at his school," and his sister leaves "red welts on his arms." However, his support for the Logans and Cassie never weakens, and "Still, Jeremy continued to meet us" (p.15).

Jeremy's support to the Logan's children and especially to Cassie continues in even more controversial and crucial circumstances. When Cassie gets in trouble with his sister Lillian Jean, Jeremy is worried for Cassie and he hurries to her support. Cassie informs the reader "I stared up at Mr Simms, frightened, Jeremy appeared frightened too" 
(p.138). Jeremy's fear is not for his sister or himself, but for Cassie. He connects and relates to her in her fear and perhaps in her victimization as well. Jeremy Simms as a white boy has nothing to fear, his only fear is for Cassie. For a moment, Cassie's experience becomes his own as well. He feels her fear, her vulnerability and her frustrations. Jeremy does not care about his father's anger and racist attitude. When his father asks Cassie to apologize, Jeremy says "She d-did Pa-Rright now, "fore y'all come, she did-" "And Mr Simms turned an angry gaze upon his son and Jeremy faltered looking at me, and hung his head" (p. 139). Even though Cassie and Jeremy are different in gender, class and race, Jeremy is able to relate and identify. Contrary to Baker's claim (2010) that Jeremy Simms is ultimately frightened into silence" (p. 130), Jeremy, in fact, never gives up and never relinquishes.

In an act of defiance to his community and family and with the desire to relate and connect with the Logans, Jeremy Simms decides to visit the Logans on Christmas day. Against the will of his father and community, Jeremy goes to the Logan family to give them a Christmas gift and a flute he made especially for Stacey Logan. Jeremy finds in Christmas a good occasion to connect with the Logans, to cross the race boundaries imposed on him by the community, and to reach out to the Logans. In a language full of hope and inspiration, Jeremy expresses his dream and vision to the Logans. He made a small house tree, and when he climbs up there, he feels "like going into another world" (p.280) — a world perhaps better than the world he lives in. "I can see, and I can hear things up there that I betcha only the squirrels and the birds can see and hear" (p.280). Jeremy's private space is the space where he can connect with the Logans: "Sometimes I think I can even see all the way over to y'all's place." If the Simms and the Logans can never connect in reality, they actually can in his mind, and in the alternative space that he created for himself. "Well... maybe I can't see it, but that don't keep me from pretending I do" (p. 280-281). Jeremy hopes to build a community of choice different from the typical community he was born and morally embedded in with an attempt perhaps to redefine his identity, ethical and ethnic values. He invites the Logans to share his space and the world he lives in. "Hey, why don't y'all come over and see it? My pa's gonna be gone all day, and it'd be lots of fun and I could show y'all-“'(p. 281). When the Logans turned down his invitation, Jeremy is ready "to accept it as a part of the things that were" (p. 281). However, the hard reality never deters his dream to connect, relate and collaborate. "If y' all ever get a chance to build y' all-selves a tree house, just let me know and I'll help ya. It's just as cool..." (281). For Jeremy, it is as cool for the Logans to have their own tree house as to share with him his own. Jeremy's relationship with the Logans and his empathy towards Cassie could have resulted in what Jordan (1995) calls a "transformative connection" that could have reestablished "the possibility of empathetic connection and mutuality. Jordan elaborates on the nature of this transformative connection:

Transformation happens, but I feel clear that it happens in the connection itself, in the experience of joining, in the sensing of respect, vulnerability, openness, engage- ment, love, moving with another person's feelings, and willingness to risk change. These are at the core of an experience of mutuality (p. 56).

As much as Jeremy exposes much of his vulnerability to Cassie, identifies with her struggle for justice, respects the noble cause that she is after, and risks much with his parents, siblings, and peers, Cassie does not reciprocate. Mutuality never occurs; Jeremy's empathy and effort to reach out and cross the boundaries of race are never reciprocated. The possibilities of affirmation, confirmation, and collaborative agency and "transcendence of the experience of separate self" to "a sense of self as part of a larger relational unit" (Jordan, 1995, p.57) is thwarted-such a possibility is aborted by the racist society. The racial prejudice and sense of injustice that the Logans and Cassie have internalized for so long has become a major pulling back force hard to overcome. Jeremy's "movement toward the other's differentness" (Jordan, 1995, p. 57) to grow and validate each other, to construct a collaborative agency and empower each other is not recognized by Cassie as a potential to achieve such ends. The very person who needs it most, Cassie Logan, mars the possibility for a mutually empowering relationship.

Cassie is not responsive to Jeremy's attempt to connect and establish a bond of mutual empowerment. In fact, she describes him to the reader as "a strange boy", and when he enthusiastically tells them about his small house tree, Cassie responds: "Ah, shoot, boy, you're a story..." "Boy, you are crazy!" (p. 323). Cassie sees Jeremy as "something of an oddity" (Hardstaff, 2015, 233). When Jeremy goes to see the Logans on Christmas day, Cassie shows no appreciation for his visit, nor for the gift that he brings for the whole family. 'Nuts?' I questioned. 'Nuts! Why, we got more nuts now than we know what -" (p. 188). Aware that Jeremy might be insulted and offended by Cassie's remark, her mother warns her: "what have I told you about that mouth of yours?" (p. 188). Cassie is not responsive to Jeremy's attempt to reach out and build a bridge between himself and the family. Moreover, Jeremy's confession that he "sure be lonely" without his Logan friends does not have any impact upon Cassie except that of surprise and disbelief. She questions "Lonely? I asked with all them brothers and sisters you got?" (p. 240). Cassie does not seem to be sensitive to Jeremy's being cut off from his brothers and peers, as he is sensitive to her pain and sense of injustice. This scene recalls another when Jeremy is afraid for Cassie upon his father asking her to apologize to Lillian Jean. Reading both scenes against each other, one hardly needs to labor the point that Cassie is not able to reciprocate the empathy and understanding that Jeremy shows towards her. His confession of his loneliness and vulnerability are responded to with her surprise and disbelief. Cassie could not see that the racist and prejudiced society that she and Jeremy live in has made both of them lonely outcasts who can have only each other's support and mutual understanding to cope with the pains and frustrations such a system causes. Cassie cannot see beyond the racial lines and cannot see Jeremy's real motivations for crossing the racial boundaries that separate them from each other. Cassie may see herself as a victim of the racist social prejudice, but cannot fathom how Jere- 
my can possibly be a victim as well. Jeremy's "secret smile" when he speaks about his sister Lillian Jean is wasted upon Cassie. Jeremy says Lillian Jean “ain't so persnickety since Cassie stopped bein' her friend.' He smiled a secret smile to himself' (p. 240) and Cassie remains non-responsive to Jeremy's intimate complicity and knowledge about her secret revenge of his sister Lillian Jean. Cassie's irresponsiveness thwarts all Jeremy's attempts to cross all the boundaries to achieve a meaningful mutually empowering friendship between both of them and subsequently between the two races. Jordan (1995) comments on the value of this mutuality and responsiveness:

In mutuality, one is both affecting the other and being affected by the other; one extends oneself out to the other and is also receptive to the impact of the other. There is openness to influence, emotional availability and constantly changing pattern of responding to and affecting the other's state. There is both receptivity and active initiative toward the other. There is a sense of expanding participation, engagement, and openness between the people involved (p. 56).

Cassie unfortunately misses the opportunity to extend herself to Jeremy and to achieve a larger sense of engagement, collaboration, and active participation.

Cassie's parents play a major role in her failure to understand and connect with Jeremy. Obviously, the adults cannot see beyond the racial lines, beyond the colors of both races, and neither can the children. Jeremy walks in on the Logan family finding himself in the middle of their stares. Uncle Hammer and David Logan insult his act of courage. Here is how the encounter between Jeremy and the Logans is described to the reader:

Stacey opened the door and found Jeremy Simms standing there looking frozen and very frightened... Everyone turned to stare at him. Stacy glanced around at Papa, then back to Jeremy. 'You - you wanna come in?' he asked awkwardly. Jeremy nodded and stepped hesitantly inside... Uncle Hammer's eyes narrowed, and he said to Papa, he looks like a Simms,'

'I believe he is,' agreed Papa.

'Then what the devil - '

'Let me handle it,' Papa said. (p. 188)

This passage is very revealing. It is clear that the children are at a loss, and do not know how to behave in such crucial moments. Moreover, the exchange between Mr. Hammer and David Logan is very ironic. "He looks like a Simms," and $\mathrm{Mr}$ David agrees, "I believe he is." The readers are well aware at this point in the narrative that Jeremy is a Simms only in appearance. He has nothing in common with his father and siblings. Mr. Hammer's and David Logan's perception of Jeremy is shaped by their racial prejudice and not by his unyielding efforts to reach out and connect with them. To borrow Martin Luther King's terms, Jeremy is judged by the color of his skin and not by the content of his character. It is obvious that Jeremy's courage and bravery to walk to their home to share with them the spirit of Christmas are not enough for them to question their prejudice and to see Jeremy for who he really is - to see clearly that he is not a Simms. Even after giving Stacey the flute that he made himself, David Logan addresses him as "Charlie Simms's boy," (p. 189) just to intensify further the irony of the beginning of the scene. David Logan's conclusion that "friendship between black and white don't mean that much "cause it usually ain't on a equal basis" illustrates how David Logan is not willing to let such a friendship grow and develop to subvert the social prejudice and injustice prevailing at that time in spite of the possible potentials that such a friendship may carry.

The circle of racism and prejudice remains unbroken and the heavy legacy of the past and the pain of the present are laid upon the future and handed down from parents to children. The victim and the victimizer equally perpetuate the system of inequality and injustice in the absence of real and genuine subversive and challenging acts to break such prejudice. The gap between both races will widen and the future generations of both races such as Cassie and Jeremy will bear the consequences of such a system that does not produce winners but only losers. Without real collaborative agency between the two races, without mutual empathy toward each other, and without recognition of the vulnerability and victimization of both races, salvation remains impossible to achieve. Racism will continue to corrupt both races. It is only with mutual empowerment and collaborative agency that races and individuals can transcend the racist mindset and create a social texture of interdependent and mutual interpersonal relations of free and more importantly interconnected individuals.

To conclude, this study attempted to examine Cassie Logan's agency and empowerment. It argued that without relating and engaging with other characters outside the circle of her race and family, Cassie's agency remains incomplete. This research proved that empowerment, if not excreted in the context of community; it cannot challenge the status quo, and be conducive to constructive and subversive changes. Connecting with others can create a transformative force and generate an impetus for activism. Cassie, by turning her back to the possibility of a fruitful relationship with Jeremy Simms, misses a great opportunity for change and defiance. This study concluded that power for change and transformation is a result of collaborative mutual interdependent and interconnected individuals.

\section{REFERENCES}

Baker, J. (2010). Racial identification and audience in roll of thunder, hear my cry and the watsons go to Birmingham-1963. Children's Literature in Education 41(2), 118-145.

Bosmajian, H. (2009). A search for law and justice in a racist society. In H. Montgomery \& N. Watson (Eds.), Children Literature: Classic Texts and Contemporary Trends (pp.231-237). New York Palgrave Macmillan.

Brooks, W. and Hampton, G. (Eds). (2005). Safe discussions rather than first hand encounters Adolescent examine racism through one historical fiction text. Children's Literature in Education 36(1), 83-98.

Collins, B. (1993). Reconstruing codependency using self-in-relation theory a feminist perspective. Social Work 38(4), 470-476. 
Collins, H. (2000). Black feminist thought, Knowledge, consciousness, and the politics of empowerment. New York: Routledge.

Friedman, M. (1989). Feminism and modern friendship dislocating the community. Ethics 99(2), 275-290.

Hardstaff, S. (2015). "Papa said that one day I would understand" examining child agency and character development in roll of thunder, hear my cry using critical corpus linguistics. Children's Literature in Education 46, 226-241.

Jordan, J. (1995). A relational approach to psychotherapy. Women \& therapy 16(4), 51-61

Jordan, J. (2010). Valuing vulnerability New Definitions of courage. Women \& Therapy 31, 209-233.

Jordan, J., Kaplan, A., Miller, B., Stiver, P., and Surrey L. (1991). Women's growth in connection writing from stone center. London The Guilford Press.

Kaplan, A. (1986). The self-in-relation implication for repression in women. Psychotherapy 23(2), 234-242.

Miller, J. (2008). Connection, Disconnection, and Violations. Feminism and Psychology 18(3), 368-380.
McDowell, K. (2009). Roll of thunder, hear my cry A culturally specific, subversive concept of child agency. In $\mathrm{H}$. Montgomery \& N. Watson (Eds.), Children Literature Classic Texts and Contemporary Trends (pp.237-247). New York Palgrave Macmillan.

Pinsent, P. (1997). Children's literature and the politics of equality. London David Fulton Publishers

Smith, P. (1994). A chronical of family honor: balancing rage and triumph in the novels of Mildred D. Taylor. In Karen Patricia Smith (Ed.), African American Voices in Young Adult Literature: Tradition, Transition, Transformation (p. 247-276). London The Scarecrow Press, Inc.

Surrey, J. (1991). Relationship and empowerment. In Jordan, J et al., 1991 (Eds.), Women's Growth in Connection Writings from the Stone Center (pp.162-181). London The Guilford Press.

Taxel, J. (1986). The black experience in children's fiction controversies surrounding award winning books. Curriculum Inquiry 16(3), 245-281.

Taylor, M. (2014). Roll of thunder, hear my cry. New York Puffin Books. 